\title{
UPTAKE AND STORAGE OF DDT
}

\author{
D. L. HARRISON \\ Research Division, Department of Agriculture, Wallaceville
}

\section{Summary}

Evidence is presented that 5 parts per million of DDT (on a feed dry matter basis) is an acceptable intake level for sheep in respect to the present New Zealand tolerance for DDT in meat fat intended for human consumption. This is based on the results of 8 trials involving approximately 150 sheep.

\section{INTRODUCTION}

SINCE DDT is a prohibited active ingredient for stock remedies in New Zealand (Anon, 1961) virtually the only source of this insecticide for stock is through the diet. Experiments have therefore been carried out in attempts to correlate oral intake of DDT with storage in body fat or with excretion in milk. with the object of establishing acceptable dietary levels of DDT for stock - acceptable in the sense that residues resulting in meat and dairy produce will be within tolerances set by health authorities for human foodstuffs.

In the case of DDT the present tolerance for meat fat is 5 parts per million (Anon., 1959). From limited trials using fattening lambs and yearling heifers, Harrison (1965) concluded that an acceptable level for DDT residues on pasture was $5 \mathrm{ppm}$ (on a feed dry matter basis). In this paper, this latter figure is critically examined in the particular case of sheep, using data assembled from 8 trials in which information on dietary DDT intake and DDT storage in body fat was available. It will be apparent that any standard set for a dietary intake level for DDT, or in fact for any insecticide, must be purposely biased on the conservative side in order to cover the many variables involved in the use of insecticides under practical farming conditions.

\section{EXPERIMENTAL AND RESULTS}

In this section brief accounts are given of the experimental design of 8 trials involving 148 sheep. Only 3 trials were designed specifically to determine an intake/storage pattern for sheep and it has been necessary for the purposes of this paper to make certain assumptions in the other trials in order to compare all trials on a similar basis:

(1) Where DDT was administered by capsule or by stomach tube, it was assumed that the feed intake for a $40 \mathrm{~kg}$ sheep was $1 / 2 \mathrm{~kg}$ dry matter/day and the quantities of insecticide administered were converted into parts per million in the feed on this basis.

(2) In grazing trials where residues were determined on pasture at the start (a) and at the end (b) of a grazing period, the geometric mean of (a) and (b) was used as a measure of the daily residue intake level over this period. 
DDT residue levels in fat shown in the tables denote maximum levels attained for any treatment except where otherwise indicated. All DDT residues on pasture are expressed on a dry matter basis.

Trial 1, 1951, Late SPring

Damp pasture 6 to 8 in. long was topdressed with DDT-superphosphate dust at the rate of $1 \mathrm{lb}$ DDT a.i. and 8 hoggets were grazed on the area immediately after treatment. The sheep were slaughtered in pairs after they had grazed for $1,2,3$ or 4 weeks. Results are given in Table 1 .

TABLE 1: TRIAL 1, 1951

\begin{tabular}{ccccc}
\hline $\begin{array}{c}\text { Grazing Period } \\
\text { after TD* } \\
\text { (days) }\end{array}$ & DDT Residues on Pasture & $\begin{array}{c}\text { DDT Residues in } \\
\text { (ppm) } \\
\text { End }\end{array}$ & $\begin{array}{c}\text { Geom. } \\
\text { Fean }\end{array}$ & \\
\hline $0-7$ & Start & & & \\
$0-14$ & 172 & 56 & 100 & 18.3 \\
$0-21$ & 172 & 30 & 56 & 15.5 \\
$0-28$ & 172 & 14 & 40 & 14.3 \\
& 172 & 12 & 30 & 8.2 \\
\hline
\end{tabular}

$*$ TD $=$ Topdressing.

Ample feed was available throughout the trial. The total rainfall was $4.9 \mathrm{in.}$

TRIAL 2, 1962, WINTER

DDT prills or DDT-superphosphate dust was applied at $2 \mathrm{lb}$ a.i. to 1 to $2 \mathrm{in}$. long pasture and groups of 3 or 4 sheep were permitted to graze the treated areas after $0,1,2,3$ or 4 week withholding periơds (Table 2).

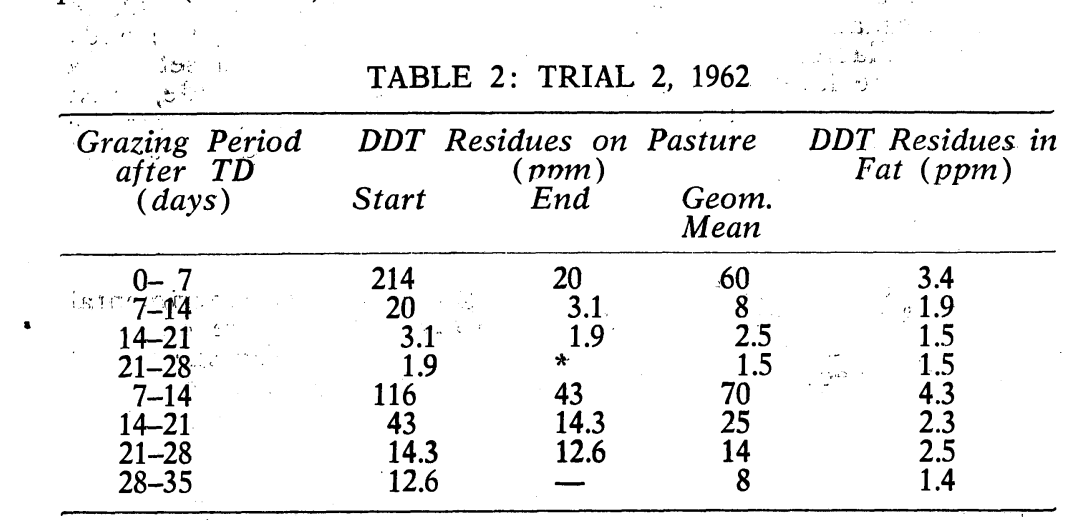

* Residue not determined.

During the trial, pasture grew approximately 2 in. and the rainfall totalled 5.31 in. DDT residues in fat were much lower than expected from the 1951 trial and this was considered due to a lack of palatable feed during this winter period. The trial was repeated in 1963. 
TRIAL 3, 1963, WINTER

DDT was applied at $2 \mathrm{lb}$ a.i. to 3 or $4 \mathrm{in}$. long pasture as prills or as DDT-superphosphate dust and groups of 3 hoggets were grazed after withholdings periods of $0,1,2$ or 3 weeks (Table 3 ).

TABLE 3: TRIAL 3, 1962

\begin{tabular}{|c|c|c|c|c|}
\hline $\begin{array}{c}\text { Grazing Period } \\
\text { after TD } \\
\text { (days) }\end{array}$ & $\begin{array}{l}D D T \\
\text { Start }\end{array}$ & $\begin{array}{c}\text { Residues on } \\
(\text { Epmd }\end{array}$ & $\begin{array}{l}\text { Pasture } \\
\text { Geom. } \\
\text { Mean }\end{array}$ & $\begin{array}{c}\text { DDT Residues in } \\
\text { Fat }(p p m)\end{array}$ \\
\hline $\begin{array}{r}0-7 \\
7-14 \\
14-21 \\
21-28 \\
0-7 \\
7-14 \\
14-21 \\
21-28\end{array}$ & $\begin{array}{r}102 \\
108 \\
74 \\
26 \\
333 \\
63 \\
51 \\
17\end{array}$ & $\begin{array}{r}108 \\
74 \\
26 \\
18 \\
63 \\
51 \\
17 \\
13\end{array}$ & $\begin{array}{r}104 \\
88 \\
43 \\
22 \\
150 \\
56 \\
29 \\
15\end{array}$ & $\begin{array}{l}2.4 \\
0.9 \\
0.2 \\
0.6 \\
2.8 \\
1.5 \\
0.6 \\
0.8\end{array}$ \\
\hline
\end{tabular}

Pasture growth was negligible during the trial and the rainfall was 5.43 in. All sheep including 6 control animals lost weight. As in the previous year, residues of DDT in the fat were low even though ample feed was available. The loss in body weight would indicate that the primary cause of the low residue in fat was unpalatability of the winter feed.

Trial 4, 1965, AUTUMN

In this trial a comparison was made of the uptake of DDT by sheep from pasture that had been treated evenly or unevenly with DDT prills. Two treatments were applied evenly at rates of $2 \mathrm{lb}$ DDT a.i. and $10 \mathrm{lb}$ DDT a.i. and a third treatment at the rate of $10 \mathrm{lb}$ DDT a.i. evenly on "bands" that occupied only $1 / 5$ th of the area treated, thus giving an average application rate of $2 \mathrm{lb}$ DDT a.i. Treatments were duplicated on pasture that was 1 to $2 \mathrm{in}$. long and dry. After topdressing, all areas were spelled for 11 days and then grazed by groups of 5 weaned lambs for 14 days. Body weight gains for all sheep during the trial ranged from 3 to $13 \mathrm{lb}$ with a mean of $7 \mathrm{lb}$. Good pasture growth gave ample feed for all animals. Results are given in Table 4.

TABLE 4: TRIAL 4, 1965

\begin{tabular}{|c|c|c|c|}
\hline$D D$ & Residues & on Pasture & DDT Residues in Fat \\
\hline Start & End & Geom. Mean & \\
\hline $\begin{array}{c}8.5 \\
4.1 \\
7 \\
9 \\
44 \\
23\end{array}$ & $\begin{array}{r}1.6 \\
1.1 \\
1.3 \\
1.8 \\
\quad 11.8 \\
7.7\end{array}$ & $\begin{array}{r}3.8 \\
2.2 \\
3.1 \\
4.2 \\
23 \\
13.5\end{array}$ & $\begin{array}{l}0.6 \\
0.7 \\
0.6 \\
0.5 \\
3.2 \\
1.7\end{array}$ \\
\hline
\end{tabular}

TrIAL 5, 1964-5.

This was a long-term oral dosing trial in which fattening lambs were given DDT at the rates of $0,1,4$ or $16 \mathrm{mg} /$ day for 16 weeks. The resulting DDT residues in omental fat removed by biopsy attained steady plateau levels after 2 to 4 weeks and these are shown in Table 5 . 
TABLE 5: TRIAL 5, 1964-5

\begin{tabular}{ccc}
\hline$D D T \begin{array}{c}\text { Intake/day } \\
(m g)\end{array}$ & $\begin{array}{c}\text { Equivalent DDT as } \\
\text { Residue on Pasture } \\
(\text { ppm })\end{array}$ & $\begin{array}{c}\text { DDT } \\
(p \text { esidue })\end{array}$ \\
\hline 0 & 0 & 0.3 \\
1 & 2 & $1 . .5$ \\
4 & 8 & 1.8 \\
16 & 32 & 3.7 \\
\hline
\end{tabular}

TRIAL 6, 1965

Groups of 4 ewe hoggets were drenched daily with either $1 / 2 \mathrm{lb}$ or $1 \mathrm{lb}$ of soil containing $47 \mathrm{ppm}$ of DDT for a period of 13 days and their body fat was analysed for DDT 2 weeks later. For comparison, other groups of hoggets were drenched with DDT in the form of fine crystals or as micronized dust at the same rate, namely, $10.7 \mathrm{mg} /$ day or $21.4 \mathrm{mg} /$ day. Results are in Table 6 .

TABLE 6: TRIAL 6, 1965

\begin{tabular}{|c|c|c|c|c|}
\hline $\begin{array}{c}\text { Formulation } \\
D D T\end{array}$ & of & $D D T \underset{(m g)}{D o s e / d a y}$ & $\begin{array}{c}\text { Equivalent } \\
D D T \text { as Residue } \\
\text { on Pasture } \\
(p p m)\end{array}$ & $\begin{array}{c}\text { DDT Residues } \\
\text { in Fat } \\
(p p m)\end{array}$ \\
\hline $\begin{array}{l}\text { Fine crystals } \\
\text { Micronized } \\
\text { In soil } \quad \ldots . . . . \\
\text { In soil } \\
\text { Controls }\end{array}$ & $\begin{array}{c}\ldots . . . \\
\ldots . . . \\
\ldots . . . \\
\ldots . . . \\
\ldots . . .\end{array}$ & $\begin{array}{c}21.4 \\
21.4 \\
10.7 \\
21.4 \\
0\end{array}$ & $\begin{array}{c}42.8 \\
42.8 \\
21.4 \\
42.8 \\
0\end{array}$ & $\begin{array}{l}0.8 \\
2.9^{*} \\
3.5^{*} \\
5.9^{*} \\
0.1^{*}\end{array}$ \\
\hline
\end{tabular}

All sheep gained in body weight except the groups dosed with soil which lost an average of $10 \mathrm{lb}$ over the 14-day period of dosing. The residues in the fat of these latter animals (marked with an asterisk) are therefore probably inflated owing to loss of depot fat through starvation.

\section{TRIALS 7 AND 8, 1964-5}

In two further trials, hoggets were given single oral doses of DDT and their fat analysed 2 weeks later. Dose rates were 1,5 and $25 \mathrm{mg} \mathrm{DDT} / \mathrm{kg}$ body weight in the form of fine crystals (Trial 7) and $10 \mathrm{mg}$ DDT $/ \mathrm{kg}$ body weight in the forms of either crystals, micronized dust or as DDT dissolved in peanut oil (Trial 8). No direct translation of the quantities administered is possible into exactly equivalent intakes as DDT residues on pasture over a 2-week period. However, for the purposes of comparing the results obtained with those of the previous trials, the total dose of DDT/sheep was considered to be divided into 14 equal daily doses which were then converted into equivalent pasture residue levels. On the logica assumption that DDT given in divided doses would be absorbed more efficiently than a single dose, the residues for DDT in fat, shown in Table 7, are probably on the low side. 
TABLE 7: TRIALS 7 AND 8, 1964-5

\begin{tabular}{clcc}
\hline $\begin{array}{c}\text { Dose Rate of } \\
\text { DDT } \\
(m g / k g b . w t)\end{array}$ & $\begin{array}{c}\text { Formulation } \\
\text { of DDT }\end{array}$ & $\begin{array}{c}\text { Equivalent } \\
\text { DDT Residue } \\
\text { on Pasture } \\
(p p m)\end{array}$ & $\begin{array}{c}\text { DDT Residues } \\
\text { in Fat } \\
(p p m)\end{array}$ \\
\hline 1 & Crystals & 5.7 & 0.6 \\
5 & Crystals & 143 & 2.1 \\
25 & Crystals & 57 & 14.4 \\
10 & Crystals & 57 & 2.2 \\
10 & Micronized dust & 57 & 5.3 \\
10 & $\begin{array}{l}\text { Dissolved in } \\
\text { peanut oil }\end{array}$ & & 4.1 \\
& Peanut &
\end{tabular}

A regression line together with $95 \%$ confidence limits (Fig. 1) was derived from the data in Tables 1 to 7 .

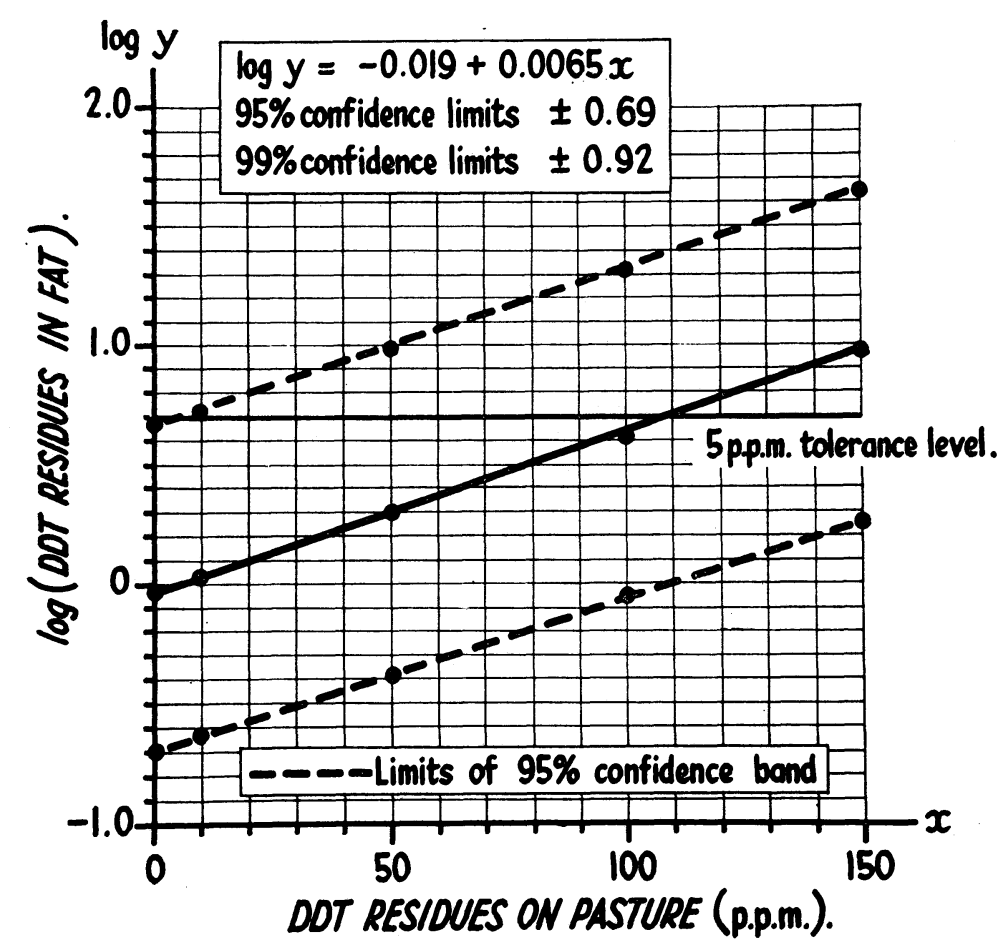

Fig. 1: Inset shows the calculated regression line of the plot.

\section{DISCUSSION!}

In these trials there was a fairly wide range of experimental conditions. DDT in dust or pelleted forms was applied to pasture that was short ( 1 to 2 in.), medium ( 3 to 4 in.) or long ( 6 to 8 in.) under dry or damp conditions. The sheep were grazed in winter autumn or spring and pasture growth during these periods varied 
from negligible to rapid. The use of pelleted and dust formulations of DDT afforded a wide range of pasture contamination levels which were exploited by varying the withholding period from nil to 4 weeks after topdressing.

There was evidence in the winter-grazing trials that low body fat residues of insecticide were the result of unpalatable pasture. The drenching trials indicated that the physical form in which DDT was administered was a major factor in the efficiency with which DDT was absorbed and stored. It is considered, therefore, that the trial conditions imposed on the test animals would cover most circumstances likely to be met under practical farming conditions

From Fig. 1 it can be deduced that sheep maintained on a level of $5 \mathrm{ppm}$ of DDT in the diet would rarely accumulate residues near the tolerance for DDT in meat fat of $5 \mathrm{ppm}$. In addition, there are two further factors mitigating against high residues ir practice. The first is that sheep introduced to feed on which the residue of DDT has fallen to a level of $5 \mathrm{ppm}$ would be exposed from then on to a decreasing DDT intake owing to the normal reduction of residues with time on growing plants. The second is that the DDT levels in fat shown in Fig. 1 represent peak levels attained after exposure and the majority of stock would not be slaughtered at peak residue times.

On this evidence, it would appear that $5 \mathrm{ppm}$ DDT on pasture (calculated on a dry matter basis) is an acceptable dietary level for sheep in respect to the New Zealand tolerance for DDT of 5 $\mathrm{ppm}$ in meat fat.

\section{ACKNOWLEDGEMENTS}

The assistance of A. Barkus in preparing the graph and of officers of the Biometrics Section for statistical evaluation of the results in the tables is gratefully acknowledged.

\section{REFERENCES}

Änon., 1959: N.Z. Gazette, 2: 913.

1961: Ibid 58: 1401

Harrison, D. L., 1965: Proc. Ruakura Farmers Conf. Week: 26. 